The recent successful molecular cloning of the viral genome of hepatitis E virus by Reyes et al represents a giant leap forward. ${ }^{2}$ Briefly, a rich source of virus was required for cloning; but as virus particles in faeces were frequently degraded and the concentration of particles by sucrose gradient centrifugation may have been complicated by the lability of the virus it was argued that intact virus might be present in gall bladder bile before its discharge into the duodenum. Indeed, aspiration of bile from the gall bladders of several infected cynomolgus macaques during the early acute phase of infection yielded a sample with a very high virus particle count on electron microscopy. Bile was used for the construction of recombinant complementary DNA (cDNA) libraries. Libraries in bacteriophage lambda gt 10 were screened by differential hybridisation with cDNA probes prepared from RNA extracted from infected and uninfected bile preparations. Several clones were identified that hybridised only to the infected bile cDNA probe. One molecular clone hybridised to a roughly $7 \cdot 6$ kilobase RNA species present only in the livers of infected cynomolgus macaques but not to any of the appropriate control preparations of DNA and RNA extracts. The translated nucleic acid sequence of a portion of the clone had a consensus amino acid motif consistent with an RNA directed RNA polymerase, an enzyme that is present in all positive strand RNA viruses. No other similarity to any known viral or non-viral sequence was detected. Furthermore, this clone identified specifically similar sequences collected from patients with enterically transmitted non-A, non-B hepatitis in Somalia, Borneo, Pakistan, and the Soviet Union. These findings suggest that a single virus, hepatitis $\mathrm{E}$ virus, is responsible for this infection in geographically diverse regions of the world-observations that are also supported by the results of immune electron microscopy.
The way is now open, therefore, for developing specific diagnostic tests for this important form of hepatitis, which accounts for over half of the cases of acute viral hepatitis in adults in many areas of the developing world and is responsible for very high mortality in pregnant women. The development of vaccines against hepatitis $E$ is now feasible.

Dean and Professor of Microbiology,

ARIE J ZUCKERMAN

Royal Free Hospital School of Medicine,

London NW3 2PF

1 Choo Q-L, Weiner AJ, Overby LR, Kuo G, Houghton M, Bradley DW. Hepatitis C virus: the major causative agent of viral non-A, non-B hepatitis. Br Med Bull 1990;46:423-41.

Reyes GR, Purdy MA, Kim JP et al. Isolation of a cDNA from the virus responsible for enterically transmitted non-A, non-B hepatitis. Science 1990:247:1335-9.

Khuroo MS. Study of an epidemic of non-A, non-B hepatitis: possibility of another hepatitis virus distinct from post-transfusion non-A, non-B type. Am $\mathcal{F}$ Med 1980;68:818-24

Wong DC, Purcell RH, Sreenivasan MA, Prasad SR, Pavri KM. Epidemic and endemic hepatitis in India: evidence for a non-A, non-B hepatitis aetiology. Lancet 1980;ii:876-9.

5 Tanden BN, Joshi YK, Jain SK, Gandhi BM, Mathiesen LR, Tandon HD. An epidemic of non-A, non-B hepatitis in north India. Indian $\mathcal{F}$ Med Res 1982;75:739-44.

6 Sergeev NW, Paktoris EA, Ananev WA, Sinajko GA, Antinova AI, Semenov EP. General characteristics of Botkin's disease occurring in Kirgiz Republic of USSR in 1955-1956. Sovetskaia Healthcare Kirgizii 1957;5:16-23.

7 Nayak NC, Panda SK, Datta R, et al. Etiology and outcome of acute viral hepatitis in pregnancy. fournal of Gastroenterology and Hepatology 1989;4:345-52.

8 Bradley DW. Enterically-transmitted non-A, non-B hepatitis. BrMed Bull 1990;46:442-61.

9 Purcell RH, Ticehurst JR. Enterically transmitted non-A, non-B hepatitis: epidemiology and clinical characteristics. In: Zuckerman AJ, ed. Viral hepatitis and liver disease. New York: Alan R Liss, 1988:131-7.

10 Balayan MS, Agafonov VI, Andzhaparidze AG, Savinskaia SS, Sgibov IA. Viral hepatitis, similar in clinical picture epidemiology to hepatitis A, but differing from it etiologically. $Z h$ Mikrobiol Epidemiol Immunobiol 1982;8:79-84.

11 Balayan MS, Andjaparidze AG, Savinskaya SS, et al. Evidence for a virus in non-A, non-B hepatitis transmitted via the fecal-oral route. Intervirology 1983;20:23-31.

12 Bradley DW, Krawczynski K, Cook EG Jr, et al. Enterically transmitted non-A, non-B hepatitis: etiology of disease and laboratory studies in nonhuman primates. In: Zuckerman AJ, ed. Viral hepatitis and liver disease. New York: Alan R Liss, 1988:138-47.

13 Krawczynski K, Bradley DW. Enterically transmitted non-A, non-B hepatitis: identification of yirus-associated antigen in experimentally infected cynomolgus macaques. $\mathcal{J}$ Infect Dis 1989; 159: 1042-9.

14 Panda SK, Datta R, Jaur J, et al. Enterically transmitted non-A, non-B hepatitis: recovery of a virus-like particle from an epidemic in south Delhi and transmission studies. Hepatology 1989;10:1-6.

15 Kane MA, Bradley DW, Shrestha SM, et al. Epidemic non-A, non-B hepatitis in Nepal: recovery of a possible etiologic agent and transmission studies in marmosets. fAMA 1984; 252:3140-5.

\title{
Policies on drugs in the new Europe
}

\section{Proposals for a uniform testing system seem likely to succeed}

The European Commission has set a target date of 1992 for the dismantling of trade barriers and the creation of a single market for goods in Europe. How is this going to affect the medicines sold and prescribed in member states?

Despite the international image of the pharmaceutical industry there are still substantial variations among European countries in the number and range of drugs available, their price, and their classification into over the counter, prescription only, and controlled categories. Furthermore, clinicians throughout the Community show wide variations in their choice of drugs from large categories such as antihypertensive drugs. Most European Community countries have a positive balance of trade in manufactured medicines, and some governments have provided incentives to ensure that most medicines used in their countries should be manufactured by home based companies. This has allowed large variations to develop among different countries of the Community. Denmark, Germany, Holland, and Ireland in general have higher prices for medicinal products than Britain, and France, Belgium, Greece, Italy, Spain, and Portugal have lower ones. The reimbursement schemes whereby patients recover the cost of their prescribed medicines differ widely. Almost all have some scheme of copayment so that the reimbursement price to the patient is of greater relevance to them than the manufacturer's price. Another factor that has to be taken into account is the wide variation in the wholesale dealers' margins permitted in different Community markets. Attempts to harmonise prices on reimbursement systems are unlikely to be tackled because the differences and philosophies are so diverse.

The European Commission has expressed the belief that if free market principles are to be applied to pharmaceuticals then after 1992 there ought to be a uniform, two tier classification of medicines available for sale either over the counter or as prescription only items. In most European countries there are only these two tiers. In Britain medicines are available variously as general sale, pharmacy only sale, or prescription only. Some commentators believe that the Commission had been contemplating breaking the pharmacists' monopoly in many European Commission countries for nonprescription medicines. Currently the Commission's plans seem limited to having a uniform prescription only category.

What have been agreed, however, are some substantial steps towards uniform European standards on the testing and approval of new drugs. The European Commission has proposed that from 1992 three systems will operate concurrently for testing and approving new medical (and veterinary) products. 
Firstly, new products derived from biotechnology will be assessed and approved by a centralised organisation. The procedure agreed by the Community will be compulsory for biological innovations, but it will also be available-at the choice of the company - for any new chemical entities whether or not derived from bioengineering methods. The current system of national regulatory agencies will continue to function, however, and this procedure will be available for the approval of conventional drugs.

The second proposal is that companies that have been given authorisation for a drug in one home country will be able to apply to other member states for them to accept this decision. The intention is that there will be autorecognition of agreements for marketing approval. If a country has doubts about accepting an authorisation of this kind (and one that cannot be resolved by discussions among the national regulatory agencies) then arbitration resulting in a binding decision will be arranged at the level of the Community.

Thirdly, it will remain possible after 1992 for small companies intending to market products only in their home country to apply for solely national registration.
This proposed three level system of regulation will require creating a central regulatory structure - a European medicines agency with committees for human and veterinary products, specialist working parties, and arbitration procedures. Decisions of the agency should be binding on member states - both its central regulatory procedures and its arbitration tasks. The agency is also expected to coordinate the existing national monitoring procedures for adverse drug reactions and for inspecting the manufacture of drugs and testing their quality.

At present these proposals are being discussed by European Community member states. ${ }^{1}$ The creation of a medicines agency whose decisions will be binding seems likely to provoke some controversy, but once agreed it will provide the framework for steady progress towards European unity on drugs - at least in terms of their scientific evaluation.

Deputy Editor, $B M \mathcal{F}$

TONY SMITH

1 The European Commission. Future system for the authorisation of medicinal products with the European Community. A discussion document. Brussels: European Commission, 1989. (III/8267/89 Revision 2.)

\section{Infectious disease control}

\section{A review of the law offers an opportunity to aid the revival of British public health}

One of the problems identified by the Acheson report, Public Health in England, was confusion about responsibility for the control of communicable diseases, including poor communication between some local and health authorities and dissatisfaction with the role of the medical officer for environmental health. ${ }^{1}$ Along with other aspects of the report some of these deficiencies have already been tackled-for example, by appointing consultants in communicable disease control. ${ }^{2}$ But the Acheson committee also pointed out the need for a review of the law on infectious disease, and the Department of Health has now responded with a consultation document. ${ }^{3}$

The key question the document poses is whether district health authorities or local authorities, or both, should have the statutory duty to provide, lead, and coordinate an infectious disease control service. ${ }^{3}$ The answer must surely be that both should, district health authorities being responsible for surveillance, investigation, control, and prevention of disease ("matters affecting persons") and local authorities being responsible for surveillance, investigation, and control of environmental hazards ("matters relating to the environment"). This clarification of responsibilities should enhance the close working relationships between medical officers for environmental health and chief environmental health officers that exist in most districts, as should the greater specialist training given to the consultants in communicable disease control than the medical officers for environmental health received in the past. Every infectious disease has an environmental component, most notably in food borne and waterborne disease, and many environmental hazards are related to infection. So consultants and chief environmental health officers would be helped to do their job if district health authorities and local authorities had a statutory requirement to provide support for each other - for example, by deploying staff when necessary. An honorary appointment of the consultants in communicable disease control to the appropriate local authorities and of the chief environmental health officer to the corresponding health authorities would help, especially if the concept of the "proper officer" to local authorities were discontinued.

If control of infection in people is to become a health authority responsibility it follows that statutory notification of infectious disease should be to district health authorities and that they should have the legal powers to deal with it. In practice, notifications should be sent in strict confidence to the consultants in communicable disease control, as the Acheson report suggested; indeed, this currently happens informally in some parts of England and Wales. The legal powers available to the consultants in communicable disease control should include exclusion from work or school, isolation of people at home or in hospital, compulsory medical examination, and entry to premises for investigating and controlling infection. Obtaining epidemiological information from individual people, either during investigation of an episode of infection or as part of an epidemiological survey, does not usually require legal powers, although occasionally these might be helpful. Most existing public health law is concerned with environmental control and is therefore a local authority function. Similarly, food law, including the lay reporting of gastrointestinal infections from food premises, should continue to be a local authority responsibility.

The consultation document describes the complexity of current legislation on statutorily notifiable infectious disease, which could be simplified by limiting the number of notifiable diseases and applying the same set of regulations to all of them. ${ }^{3}$ Notification should be confined to those diseases that require urgent control measures or for which legal powers might be required and those for which preventive programmes, such as immunisation, are in progress or likely to begin soon. The consultation document suggests two lists: one of diseases for immediate action and the other of those for surveillance. But two lists would cause confusion, and a single list with internationally accepted case definitions would be preferable. Some of the existing 29 notifiable diseases could be 